\title{
Photocatalytic antibacterial and osteoinductivity
}

\author{
S. Wageh ${ }^{a, *}$, Ahmed A. Al-Ghamdi a , Lijun Liu ${ }^{\text {b,\# }}$
}

Implants of titanium (Ti) and its alloys have been widely used for decades in bone tissue engineering. Orthopedic implantation is unavoidably accompanied by bacterial infection, which requires extensive surgical intervention and antibiotic therapy. These infections increase the risk of implant failure and bone loss and can result in limb amputation in severe cases. Repeated antibiotic treatment also induces irreversible drug resistance in humans [1,2]. Studies designed to optimize Ti containing implants have focused on surface modification or improvements of topological structures. Modified implants can induce stem cell differentiation and bone regeneration [3]. However, designing implants that resist colonization by bacteria has not been explored extensively.

Photocatalytic antibacterial compounds have formed an interdisciplinary research hotspot by amalgamating photocatalysis and medicine. One such example is Ti dioxide $\left(\mathrm{TiO}_{2}\right)$, an inert, stable, abundantly available, and environmentally benign photocatalyst $[4,5]$. Photocatalytic sterilization has been explored for decades. Under ultraviolet (UV) light irradiation, implants containing $\mathrm{TiO}_{2}$ produce reactive oxygen species (ROS) that include hydroxyl radicals $(\bullet \mathrm{OH})$, superoxide anions $\left(\bullet \mathrm{O}_{2}-\right)$, and hydrogen peroxide $\left(\mathrm{H}_{2} \mathrm{O}_{2}\right)$. These ROS exhibit strong oxidative activities. They attach to cellular components and the resulting perforation and destruction of bacterial membranes is lethal. This in situ sterilization of implants simultaneously prevents bacterial infection and induces osteogenesis [6]. However, similar to the majority of single component photocatalysts, ROS production stimulated by pristine $\mathrm{TiO}_{2}$ is poor owing to its rapid electron/hole recombination. This impedes achieving the desired antibacterial effects.

As an emerging carbon allotrope, graphdiyne (GDY) has a unique electronic structure, high conductivity, good stability, and biocompatibility. GDY is a promising electron cocatalyst that can trap photoinduced electrons of $\mathrm{TiO}_{2}$ and help achieve efficient ROS production by promoting the separation of photocarriers. GDY consists of abundant $s p$ - or $s p^{2}$-hybridized carbon atoms. The $s p$ or $s p^{2} \pi$-electrons are readily delocalized, which may permit the chemisorption of osteoblasts and induction of bond formation after in vivo implantation $[7,8]$. The delocalized electrons also induce a strong interfacial interaction between GDY and $\mathrm{TiO}_{2}$ upon their hybridization. $\mathrm{TiO}_{2} / \mathrm{GDY}$ hybrids have attracted attention as potential candidate materials for orthopedic implants, which feature both tissue regeneration capability and antibacterial effects.

Recently, Wang et al. [9] reported a $\mathrm{TiO}_{2} / \mathrm{GDY}$ hybrid photocatalyst with enhanced photocatalytic bioactivity that was fabricated via electrostatic assembly of positively charged electrospun $\mathrm{TiO}_{2}$ nanofibers and negatively charged GDY nanosheets. The hybrid enhanced photocatalytic ROS production and efficiently sterilized bacteria by oxidizing bacterial components. The authors reported that $\mathrm{TiO}_{2} / \mathrm{GDY}$ hybrid disrupted biofilms of methicillin-resistant Staphylococcus aureus and inhibited nascent biofilm formation. The antibacterial property of $\mathrm{TiO}_{2} /$ GDY hybrid was prolonged even in the absence of UV irradiation. This phenomenon could be attributed to the sustained release of the $\mathrm{H}_{2} \mathrm{O}_{2}$ photocatalytic-produced ROS. In vivo, GDY promoted the biocompatibility of $\mathrm{TiO}_{2}$ nanofibers, which enabled $\mathrm{TiO}_{2} / \mathrm{GDY}$ hybrid with effective adsorption of osteoinductive dexamethasone. The presence of dexamethasone on $\mathrm{TiO}_{2} / \mathrm{GDY}$ hybrid induced the expression of proteins and enzymes needed for bone differentiation, thereby favoring mineral deposition. The results indicated the promising osteoinductivity abilities of $\mathrm{TiO}_{2} / \mathrm{GDY}$ nanofibers and their potential value in orthopedic implants for bone regeneration.

In general, $\mathrm{TiO}_{2} / \mathrm{GDY}$ hybrid displayed enhanced photocatalytic antibacterial effects and long-term osteoinductive ability. The mechanisms underlying their effects is illustrated in Fig. 1. Briefly, under UV light irradiation, the photoexcited electrons in the $\mathrm{TiO}_{2}$ conduction band are transferred to GDY, achieving a prolonged lifetime of photocarriers, which benefits ROS production and sterilization [10,11]. The osteoblast cells are readily adsorbed and spread on the $\mathrm{TiO}_{2} /$ GDY hybrid surface because of their excellent biocompatibility and hydrophilicity, which favors bone tissue regeneration. The findings describe an emerging orthopedic implant $\left(\mathrm{TiO}_{2} / \mathrm{GDY}\right)$ and support the novel concept that well-designed photocatalysts can offer antibacterial activity and osteoinductivity to improve the quality of implantation.

In summary, previously designed GDY-modified $\mathrm{TiO}_{2}$ nanofibers [9] can promote the photocatalytic antibacterial effect and long-term osteoinductive capability of implants. GDY exhibited excellent electron-trapping ability, photothermal con- 


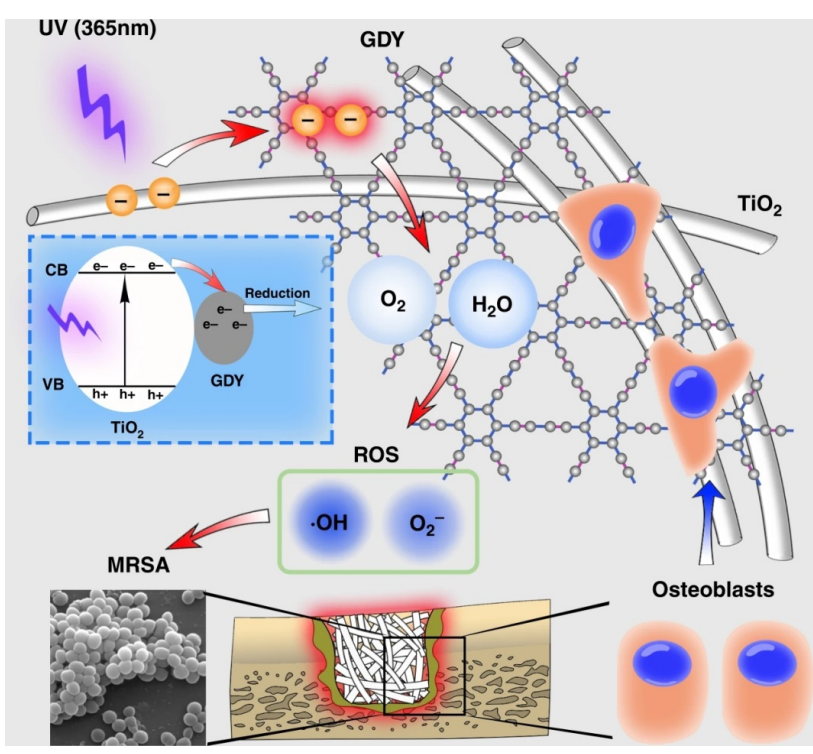

Fig. 1. Schematic of the dual function of $\mathrm{TiO}_{2} / \mathrm{GDY}$ hybrid in orthopedic implant infection. Copyright 2020, Springer Nature [9].

version efficiency, and biocompatibility. This pioneering work suggests that $\mathrm{TiO}_{2} / \mathrm{GDY}$ could be used as a dual-functional implant with robust antibacterial performance and osteoinductivity. Inspired by this innovative work, GDY is expected to be utilized to construct more advanced orthopedic implants with photocatalytic ROS production activity. Further efforts should seek to enhance the adhesion strength between GDY and implants and improve biocompatibility, photoactivity, and bioactivity of the composite implants. In addition to the osteoinductivity, GDY can be applied as an electron cocatalyst in environmental and energy photocatalytic activities, including solar-driven $\mathrm{CO}_{2}$ reduction, photocatalytic water splitting, and organic photosynthesis owing to its promising $\mathrm{CO}_{2}$ activation ability, light harvesting, and charge separation efficiency. The present findings will encourage collective efforts to develop more efficient GDY-involved photocatalysts for photocatalytic, antibacterial, osteoinductivity, and solar-driven chemical reactions.

\section{Acknowledgments}

This work was supported by the Deanship of Scientific Research (DSR) at King Abdulaziz University, Jeddah (RG-50-130-41). The authors, therefore, acknowledge with thanks DSR for technical and financial support.

\section{S. Wageh}

Department of Physics, Faculty of Science,

King Abdulaziz University, Jeddah 21589, Saudi Arabia

E-mail: wswelm@kau.edu.sa

Lijun Liu

College of Chemistry and Chemical Engineering,

Wuhan Textile University, Wuhan 430200, China

Tel: +86-27-59367685

E-mail: liulj@wtu.edu.cn

Received 3 November 2020

Accepted 25 November 2020

Available online 5 March 2021

DOI: $10.1016 / S 1872-2067(20) 63742-1$

\section{References}

[1] M. J. Limo, A. Sola-Rabada, E. Boix, V. Thota, Z. C. Westcott, V. Puddu, C. C. Perry, Chem. Rev., 2018, 118, 11118-11193.

[2] B. Y. Li, T. J. Webster, J. Orthop. Res., 2018, 36, 22-32.

[3] L. Bai, Z. B. Du, J. J. Du, W. Yao, J. M. Zhang, Z. M. Weng, S. Liu, Y. Zhao, Y. L. Liu, X. Y. Zhang, X. B. Huang, X. H. Yao, R. Crawford, R. Q. Hang, D. Huang, B. Tang, Y. Xiao, Biomaterials, 2018, 162, 154-169.

[4] J. Shen, R. Wang, Q. Q. Liu, X. F. Yang, H. Tang, J. Yang, Chin. J. Catal., 2019, 40, 380-389.

[5] F. He, A. Y. Meng, B. Cheng, W. K. Ho, J. G. Yu, Chin. J. Catal., 2020, $41,9-20$.

\section{Graphical Abstract}

Chin. J. Catal., 2021, 42: 1051-1053 doi: 10.1016/S1872-2067(20)63742-1

\section{Photocatalytic antibacterial and osteoinductivity}

S. Wageh*, Ahmed A. Al-Ghamdi, Lijun Liu*

King Abdulaziz University, Saudi Arabia;

Wuhan Textile University, China

Graphdiyne-modified $\mathrm{TiO}_{2}$ nanofibers, which could be incorporated into orthopedic implants, have impressive self-antibacterial and osteoinductive abilities due to their efficient ROS production, favorable osteoblast adsorption, and good biocompatibility.

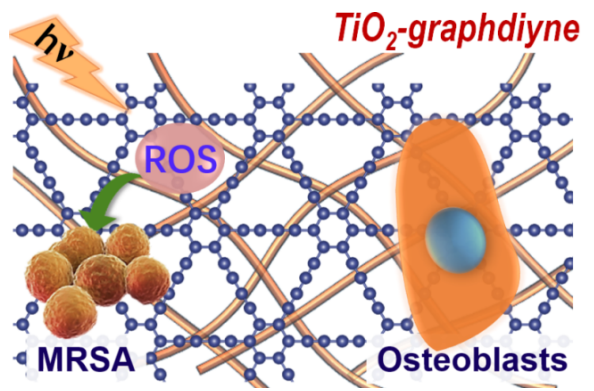


[6] P. V. Laxma Reddy, B. Kavitha, P. A. Kumar Reddy, K. H. Kim, Environ. Res., 2017, 154, 296-303.

[7] P. Y. Kuang, B. C. Zhu, Y. L. Li, H. B. Liu, J. G. Yu, K. Fan, Nanoscale Horiz., 2018, 3, 317-326.

[8] F. Y. Xu, K. Meng, B. C. Zhu, H. B. Liu, J. S. Xu, J. G. Yu, Adv. Funct. Mater., 2019, 29, 1904256.
[9] R. Wang, M. S. Shi, F. Y. Xu, Y. Qiu, P. Zhang, K. L. Shen, Q. Zhao, J. G. Yu, Y. F. Zhang, Nat. Commun., 2020, 11, 4465.

[10] T. Hu, K. Dai, J. F. Zhang, S. F. Chen, Appl. Catal. B, 2020, 269, 118844.

[11] F. Y. Xu, K. Meng, B. Cheng, S. Y. Wang, J. S. Xu, J. G. Yu, Nat. Commun., 2020, 11, 4613.

\title{
光催化杀菌和诱导骨组织生长
}

\author{
S. Wageh ${ }^{\mathrm{a}, *}$, Ahmed A. Al-ghamdi ${ }^{\mathrm{a}}$, 刘丽君 ${ }^{\mathrm{b}, \#}$ \\ a阿卜杜勒阿齐兹国王大学理学院物理系, 吉达 21589 , 沙特阿拉伯 \\ $\mathrm{b}$ 武汉纺织大学化学与化工学院, 湖北武汉 430200 , 中国
}

\begin{abstract}
摘要: 钛合金植入体具有良好的生物相容性和化学稳定性, 广泛应用于整形外科手术. 植入手术细菌感染风险较高, 若处 理不当, 易造成患者骨组织损失甚至截肢. 光催化杀菌是光催化领域研究热点之一, 光催化剂表面产生的活性氧物种 (ROS)氧化能力强, 可有效杀灭细菌. 制备生物相容性好且光催化活性高的植入体, 利用光催化技术, 可实现术后植入体表 面自主产生抗菌活性, 同时诱导骨组织细胞原位生长和成骨. 二氧化钛 $\left(\mathrm{TiO}_{2}\right)$ 光催化剂化学稳定性好, 原料易得, 具有一定 的生物相容性, 但其光生电子与空穴易复合, 光催化抗菌活性弱. 石墨炔(GDY)是新兴的电子助催化剂, 具有独特的 $s p$ 和 $s p^{2}$ 杂化碳原子, 可以捕获 $\mathrm{TiO}_{2}$ 的光生电子, 促进光生电子/空穴分离和ROS生成. 基于此, 张玉峰教授(武汉大学)和余家国教授 (武汉理工大学)近期报道了一种新型的具有光催化生物活性的 $\mathrm{TiO}_{2} / \mathrm{GDY}$ 复合植入体 (Nat. Commun., 2020, 11, 4465). 它由带 正电的 $\mathrm{TiO}_{2}$ 纳米纤维和带负电的 $\mathrm{GDY}$ 纳米片通过静电自组装而成. 在紫外光照射下, $\mathrm{TiO}_{2} / \mathrm{GDY}$ 植入体能够产生羟基自由 基 $(\cdot \mathrm{OH})$, 超氧阴离子 $\left(\cdot \mathrm{O}^{2-}\right)$ 和过氧化氢 $\left(\mathrm{H}_{2} \mathrm{O}_{2}\right)$ 等活性氧物种. 原位生成的活性氧物种具有较强的氧化能力, 可以破坏抗药 性金黄色葡萄球菌(MRSA)的生物膜, 还能抑制MRSA新细菌生物膜的形成和代谢. 光照生成的 $\mathrm{H}_{2} \mathrm{O}_{2}$ 具有持续缓释特性, 在 紫外光移除后, $\mathrm{TiO}_{2} / \mathrm{GDY}$ 植入体仍显示出长期的抗菌活性. 此外, $\mathrm{TiO}_{2} / \mathrm{GDY}$ 具有良好的生物相容性和亲水性, 有效吸附小 鼠成骨细胞并诱导产生骨骼分化所需的蛋白质和酶, 表明 $\mathrm{TiO}_{2} / \mathrm{GDY}$ 纳米纤维具有良好的诱导骨组织生长能力. 该工作创 新性地将光催化技术应用于骨科植入体, 提出了植入体原位光催化杀菌和诱导骨组织生长的新思路, 实现了材料学和医学 的交叉融合, 为开发其他高效植骨材料提供了有益借鉴.
\end{abstract}

关键词: 石墨炔; 活性氧物种; 抗菌性; 诱导骨组织生长; 生物相容性

收稿日期: 2020-11-03. 接受日期: 2020-11-25. 上网时间: 2021-03-05.

*通讯联系人. 电子信箱: wswelm@kau.edu.sa

通讯联系人. 电话: (027)59367685; 电子信箱: 1iulj@wtu.edu.cn

基金来源：阿卜杜勒阿齐兹国王大学DSR资助项目(RG-50-130-41).

本文的电子版全文由Elsevier出版社在ScienceDirect上出版(https://www.sciencedirect.com/journal/chinese-journal-of-catalysis). 